\title{
Aktivitas Antiasma Rebusan Kombinasi Daun Sembung (Blumea balsamifera L. DC.), Herba Patikan Kebo (Euphorbia hirta L.), Biji Kemukus (Piper cubeba L.) Dan Rimpang Teki (Cyperus rotundus Linn.) Pada Marmut Jantan Secara In Vitro Dan In Vivo
}

\section{Antiasthma Activity Of Combination Of Decoction Of Sembung Leaves (Blumea balsamifera L. DC.), Patikan Kebo Herbs (Euphorbia hirta L.), Kemukus Seeds (Piper cubeba L.), and Teki Rhizomes (Cyperus rotundus Linn.) at Male Guinea Pig In Vitro and In Vivo}

Kiki Damayanti ${ }^{1, *}$, Agung Endro Nugroho ${ }^{2}$, dan Arief Nurrohmad ${ }^{2}$

${ }^{1}$ Fakultas Farmasi, Universitas Setia Budi

${ }^{2}$ Fakultas Farmasi, Universitas Gadjah Mada

\begin{abstract}
ABSTRAK
Secara empiris, rebusan kombinasi daun sembung, herba patikan kebo, biji kemukus, dan rimpang teki telah digunakan untuk menangani asma. Secara individu keempat tanaman tersebut telah diketahui beraktivitas sebagai obat asma. Penelitian ini bertujuan untuk mengetahui aktivitas rebusan kombinasi keempat tanaman tersebut dalam beberapa perbandingan sebagai antiasma secara in vitro dan in vivo.

Pengujian aktivitas antiasma secara in vitro dilakukan menggunakan otot polos trakea marmut terisolasi yang direndam dalam bufer Krebs bebas ion kalsium. $\mathrm{CaCl}_{2}$ digunakan sebagai induktor kontraksi otot polos trakea marmut. Persen kontraksi otot polos trakea marmut sebelum dan sesudah perendaman rebusan dibandingkan untuk menyatakan adanya aktivitas sebagai penghambat kontraksi akibat peningkatan kadar ion kalsium intraseluler. Aktivitas antiasma secara in vivo diketahui menggunakan marmut yang diinduksi dengan ovalbumin secara sub kutan dan nebulasi sebagai model hewan uji asma. Marmut asma diberi rebusan antiasma selama 29 hari. Otot polos trakea marmut dibuat preparat dengan pewarna hematoksilin dan eosin untuk mengetahui jumlah eosinofil dan persen udem yang terjadi.

Hasil penelitian menunjukkan bahwa salah satu jenis rebusan mempunyai aktivitas dalam menghambat kontraksi otot polos trakea marmut akibat peningkatan kadar ion kalsium intraseluler pada menit ke $14-26$. Tidak ada perbedaan jumlah eosinofil dan persen udem pada preparat trakea marmut yang diberi rebusan dibandingkan marmut yang diberi aquadest, sehingga secara in vivo rebusan tidak mempunyai efek sebagai penghambat infiltrasi eosinofil dan penghambat udem.
\end{abstract}

Kata kunci: Rebusan, asma, in vitro, in vivo

\section{ABSTRACT}

Empirically, combination of decoction of sembung leaves, patikan kebo herbs, kemukus fruits, and teki rhizomes has been used to relief asthma. Individually, those plants known had activity as antiasthma. The goal of the research are to assess the activity of combination of decoction in different proportion as antiasthma in vitro and in vivo.

The antiasthma activity testing in vitro is done using isolated guinea pig traceal muscle in the Krebs Buffer without calcium. $\mathrm{CaCl}_{2}$ used as inductor of trachea smooth muscle contraction. Percent of contraction before and after immersion of decoction compared to reveal the activity of decoction as a smooth muscle contraction inhibitor. The antiasthma activity in vitro testing is done using guinea pig as asthma animal model. Asthma inductor was subcutan and nebulation of ovalbumin. Asthma guinea pig were given combination of decoction for 29 days. Tracheal smooth muscle stained with hematoxilin-eosin to count eosinophils, and percent of edema.

The result showed that one kind of decoction has activity as contraction inhibitor of smooth muscle trachea at minute $14-26$. There was no different eosinophil count and percent 
of smooth muscle edema. The decoction has no activity as eosinophil infiltration inhibitor and edema of smooth muscle trachea.

Keywords: decoction, asthma, in vitro, in vivo

\section{PENDAHULUAN}

Asma merupakan gangguan kronis pada saluran pernafasan yang komplek dan dikarakterisasi dengan gejala yang bervariasi dan berulang, penghambatan aliran udara, hiperesponsivitas bronkial dan inflamasi (USDHHS, 2007). Prevalensi asma di Indonesia secara nasional dilaporkan melalui riset kesehatan dasar (Riskesdas) sebesar 4,5\%. Kelompok usia yang menderita asma didominasi oleh kelompok usia 15 - 44 tahun yang merupakan kelompok usia produktif (Kemenkes RI, 2013). Prevalensi, morbiditas, mortalitas dan beban ekonomi merupakan bentuk beban akibat asma. Secara global, asma menyebabkan 180.000 kematian setiap tahunnya. Sebagian besar kematian dialami pasien asma yang usianya lebih dari 45 tahun, meskipun sebenarnya kematian tersebut dapat dihindarkan. Kematian terutama disebabkan tidak adekuatnya terapi pemeliharaan dan terlambatnya penanganan saat serangan akut. Beban ekonomi akibat asma di negara-negara barat bervariasi antara \$ 300 hingga \$ 1.300 per pasien per tahun, tergantung pada keparahan asma (Braman, 2006).

Penyakit asma yang bersifat kronis membutuhkan terapi jangka panjang. Konsekuensi logis dari terapi jangka panjang berupa beban finansial menjadi tak terelakkan. Semakin mahalnya biaya pengobatan telah ikut mendorong pemanfaatan kembali bahan alam untuk pengobatan. Proporsi rumah tangga yang memanfaatkan pelayanan kesehatan tradisional berupa penggunaan ramuan dalam setahun terakhir sebesar 49,0\% (Kemenkes RI, 2013). Penggunaan obat tradisional di Indonesia didukung dengan fakta bahwa distribusi tumbuhan tingkat tinggi yang terdapat di hutan tropis Indonesia lebih dari $12 \%$ dari yang terdapat di muka bumi (250.000) (Sulandjari, 2009). Hasil penelitian yang dilakukan oleh Chen et al. (2016) mengungkapkan bahwa $36,8 \%$ responden yang menderita asma menggunakan pengobatan komplementer dan alternatif selama setahun terakhir. Pengobatan komplementer dan alternatif berupa obat-obatan herbal digunakan oleh $10,1 \%$ penderita asma. Di antara sekian banyak jenis tumbuhan di Indonesia, sebagian sudah digunakan secara turun temurun sebagai obat tradisional termasuk untuk menangani asma. Penggunaan obat tradisional perlu disertai dengan kajian ilmiah agar penggunaannya menjadi lebih rasional. Kajian ilmiah dapat membantu menentukan efektivitas dan keamanan obat tradisional.

Secara individu, daun sembung, herba patikan kebo, biji kemukus, dan rimpang teki telah diketahui mempunyai aktivitas antiasma. Keempat tanaman tersebut juga diketahui mengandung flavonoid (Nessa et al., 2005, Kumar et al., 2010, Nahak dan Sahu, 2011, Krishna dan Renu, 2013). Uji klinik terhadap flavonoid mengungkapkan efek perbaikan gejala yang 
berhubungan dengan asma (Tanaka dan Takahashi, 2013). Penelitian ini bertujuan untuk mengetahui aktivitas kombinasi daun sembung, herba patikan kebo, biji kemukus, dan rimpang teki dalam bentuk rebusan sebagai antiasma secara in vitro dan in vivo.

\section{METODE PENELITIAN}

\section{Bahan}

Simplisia sebagai bahan uji terdiri dari daun sembung, herba patikan kebo, biji kemukus, dan rimpang teki. Bahan-bahan yang digunakan untuk membuat bufer Krebs terdiri dari $\mathrm{NaCl}$ (Nacalai Tesque), $\mathrm{KCl}$ (Merck), $\mathrm{MgSO}_{4} .7 \mathrm{H}_{2} \mathrm{O}$ (Merck), EDTA (Merck), $\mathrm{NaH}_{2} \mathrm{PO}_{4} .2 \mathrm{H}_{2} \mathrm{O} \quad$ (Merck), $\mathrm{NaHCO}_{3}$ (Merck), dan glukosa (Nacalai Tesque). Bahan kimia lain yang digunakan adalah formalin, $\mathrm{KCl}$ (Merck), ovalbumin (Nacalai Tesque), $\mathrm{Al}(\mathrm{OH})_{3}$ (Merck), dan verapamil $\mathrm{HCl}$. Organ trakea dibuat preparat dengan pewarna hematoksilin dan eosin. Gas yang digunakan untuk aerasi bufer Krebs dalam organ bath adalah campuran $95 \%$ oksigen dan $5 \%$ karbondioksida (PT Samator). Bahan untuk mengikat trakea dalam organ bath adalah benang bedah. Air yang digunakan untuk melakukan percobaan dengan organ terisolasi adalah sterile water for irrigation USP (PT Otsuka). Air non steril yang digunakan adalah aqua destillata yang diperoleh dari Laboratorium Kimia Instrumental, Fakultas Farmasi, Universitas Gadjah Mada.
Alat

Alat yang digunakan untuk preparasi organ adalah gunting bedah (Surgical Sutures, Bio-Dynamics) dan scalpel blade (Aesculap, B Braun). Alat pengujian secara in vitro terdiri dari pengaduk magnetik termostat ( $B$ Braun), pengatur suhu organ bath, transduser isotonik (Level Transduser tipe 368, HSE), rekorder (Kipp and Zonnen, BBD 41), dua set organ bath, bridge amplifier (tipe 336, HHS), dan pipet mikro berbagai ukuran (Gilson). Selain itu, alat-alat lain yang digunakan dalam penelitian ini adalah nebulizer (Omron NE-C 28), mikroskop, spuit injeksi (Terumo), timbangan bahan (Ohaus) dan timbangan hewan uji.

Hewan Uji

Hewan uji yang digunakan dalam penelitian ini adalah marmut jantan (Cavia porcellus) dengan berat badan 400 - $600 \mathrm{~g}$ dan berumur di atas tiga bulan. Marmut diperoleh dari Laboratorium Farmakologi dan Toksikologi Fakultas Farmasi UGM.

\section{Jalannya Penelitian}

Pembuatan Rebusan

Cara pembuatan rebusan mengadopsi cara pembuatan infus yang tertera dalam Farmakope Indonesia edisi III (Depkes RI, 1979). Perbandingan tiga kombinasi rebusan antiasma yang terdiri dari campuran daun sembung, herba patikan kebo, biji kemukus, dan rimpang teki terangkum dalam tabel 1.

Tabel 1. Perbandingan kombinasi rebusan antiasma

\begin{tabular}{lccc}
\hline Komponen & Rebusan antiasma 1 & Rebusan antiasma 2 & Rebusan antiasma 3 \\
\hline Daun sembung & $31,25 \%$ & $16,04 \%$ & $10,14 \%$ \\
\hline Herba patikan kebo & $18,75 \%$ & $27,99 \%$ & $34,56 \%$ \\
\hline Biji kemukus & $18,75 \%$ & $22,39 \%$ & $13,82 \%$ \\
\hline Rimpang teki & $31,25 \%$ & $33,58 \%$ & $41,47 \%$ \\
\hline
\end{tabular}


Sepuluh gram campuran simplisia dicampur dengan aqua destillata sampai $100 \mathrm{ml}$. Campuran dipanaskan di atas penangas air hingga suhunya mencapai $90^{\circ} \mathrm{C}$. Pemanasan dilakukan selama 30 menit semenjak campuran mencapai suhu $90^{\circ} \mathrm{C}$. Selama pemanasan campuran sesekali diaduk. Setelah 30 menit campuran didinginkan, kemudian dipisahkan ampasnya dengan cara disaring dengan kain flanel. Ampas ditambah aqua destillata panas secukupnya hingga diperoleh volume $100 \mathrm{ml}$. Rebusan selalu dibuat baru.

\section{Preparasi Trakea Marmut}

Marmut dikorbankan dengan cara dislokasi leher dan trakea segera dipisahkan dari tubuh marmut. Trakea kemudian diletakkan dalam cawan yang berisi bufer Krebs secukupnya. Jaringan-jaringan yang melekat di trakea marmut dibersihkan. Trakea yang sudah bersih dipotong dengan cara sedemikian rupa sehingga membentuk pita dengan panjang disesuaikan dengan panjang tabung organ bath. Kedua ujung tulang rawan pita trakea diikat dengan benang bedah. Salah satu ujung dikaitkan dengan tuas bagian bawah pada organ bath, sedangkan ujung yang lain diikatkan pada bagian yang terhubung dengan transduser (Lee et al., 1997).

\section{Uji Aktivitas Penghambat Kontraksi}

\section{Akibat Peningkatan Kadar Ion} Kalsium Intraseluler

Otot polos trakea yang sudah diekuilibrasi hingga stabil dalam organ bath berisi bufer Krebs bebas ion kalsium sebanyak $20,0 \mathrm{ml}$ diberi $\mathrm{KCl} 5 \mathrm{~N}$ sebanyak $200 \mu \mathrm{l}$. Kontraksi otot polos trakea yang terjadi akan tercatat pada rekorder. Setelah kontraksi maksimal, dilakukan pemberian $\mathrm{CaCl}_{2} 2 \mathrm{M}$ sebanyak $100 \mu \mathrm{l}$. Kontraksi yang terjadi hingga maksimum disebut kontrol. Otot polos trakea kemudian dicuci dengan penggantian bufer Krebs bebas ion kalsium setiap 10 menit. Bila respon kontraksi sudah hilang, ditambahkan $200 \mu \mathrm{KCl} 5 \mathrm{~N}$. Selanjutnya dilakukan inkubasi otot polos trakea dengan rebusan antiasma sebanyak $200 \mu \mathrm{l}$ selama 10 menit. Setelah 10 menit dilakukan pemberian $\mathrm{CaCl}_{2}$ kembali seperti sebelum pencucian otot polos trakea. Verapamil $\mathrm{HCl}$ kadar $2 \times 10^{-3} \mathrm{M}$ sebanyak $100 \mu \mathrm{l}$ diinkubasi ke dalam organ bath sebagai kontrol positif (Pang et al., 2002).

Uji Aktivitas Penghambat Infiltrasi Eosinofil dan Penghambat Udem

Langkah sensitisasi marmut dilakukan dengan cara menginjeksi marmut secara subkutan dengan suspensi yang mengandung $10 \mu \mathrm{g}$ ovalbumin dan $1 \mathrm{mg} \mathrm{Al}(\mathrm{OH})_{3}$ dalam 0,5 $\mathrm{ml}$ larutan $\mathrm{NaCl} 0,9 \%$. Dosis yang disuntikkan adalah $0,5 \mathrm{ml} / \mathrm{kgBB}$. Suspensi diinjeksikan kembali pada hari ke 14 sesudah penyuntikan pertama. Pada hari ke 15 dimulai pemberian rebusan antiasma sampai hari ke 29. Rebusan antiasma diberikan secara per oral dengan dosis $12 \mathrm{ml} / \mathrm{kgBB}$. Nebulasi pada marmut dilakukan dengan $0,25 \%$ ovalbumin dalam $\mathrm{NaCl} 0,9 \%$ selama 10 menit pada hari ke 18, 21, 24, dan 29. Dua puluh empat jam setelah nebulasi hari ke 29, marmut dikorbankan, trakeanya diambil, kemudian dibuat preparat (Mahajan dan Metha, 2011). Preparat otot polos trakea marmut diwarnai dengan pewarna hematoksilin dan eosin untuk menghitung jumlah eosinofil dan menentukan persen udem. 
Persen udem dihitung dengan membagi tebal udem $(\mu \mathrm{m})$ dengan tebal mukosa serosa $(\mu \mathrm{m})$, kemudian dikali $100 \%$.

\section{Hasil dan Pembahasan}

Hasil Uji Aktivitas Penghambat Kontraksi Akibat Peningkatan Kadar Ion Kalsium Intraseluler

Ion kalsium berperan dalam kejadian asma. Kalsium terlibat dalam kontraksi eksitasi otot polos bronkial dan juga proses sekresi mediator dari sel mast yang menyebabkan inflamasi dan bronkokonstriksi. Depolarisasi cairan intraseluler akan membuka kanal ion kalsium di membran sel, sehingga kalsium di luar sel akan masuk ke dalam sel. Meningkatnya kadar kalsium dalam sel selanjutnya menimbulkan kontraksi sel otot polos. Depolarisasi cairan intraseluler dalam penelitian ini dilakukan dengan cara menambahkan $\mathrm{KCl}$ dalam organ bath. $\mathrm{CaCl}_{2}$ yang ditambahkan akan menimbulkan kontraksi otot polos trakea. Kurva hubungan rata-rata persen kontraksi setelah perendaman otot polos trakea dengan rebusan antiasma 3 dan verapamil $\mathrm{HCl}$ versus waktu tersaji dalam gambar 1 dan 2 .

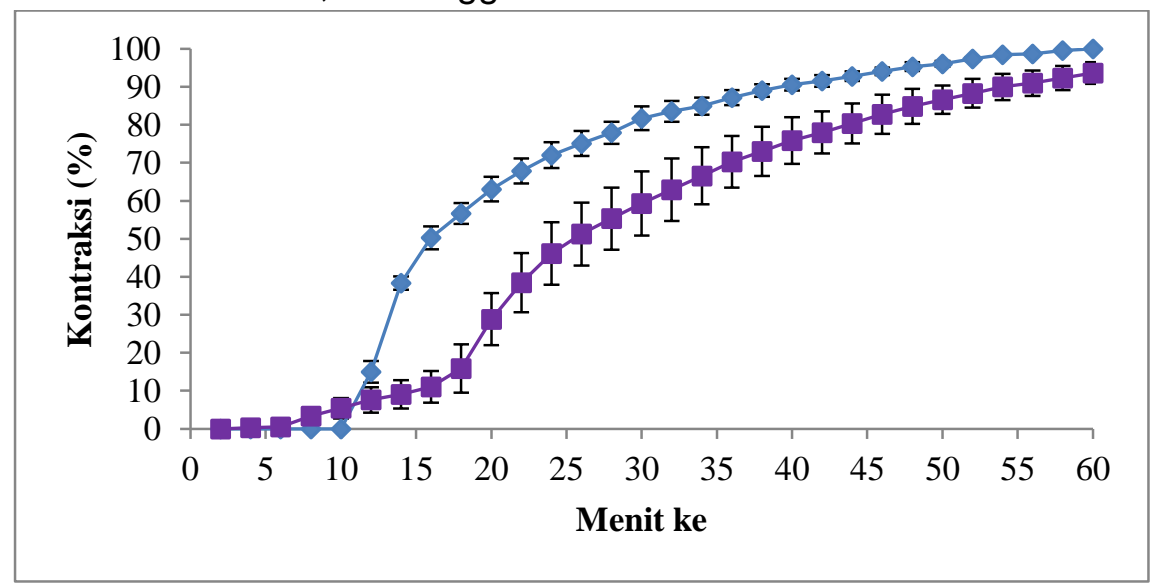

Gambar 1. Kurva hubungan persen kontraksi otot polos trakea marmut terisolasi versus waktu sebelum (--^--) dan sesudah (-----) perendaman rebusan antiasma 3

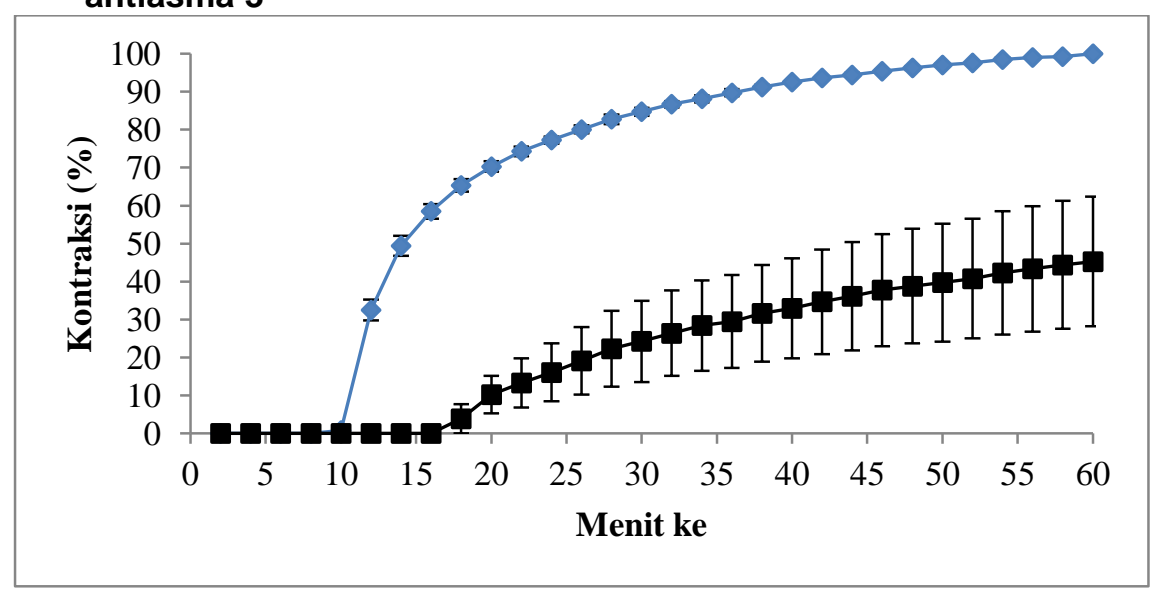

Gambar 2. Kurva hubungan persen kontraksi otot polos trakea marmut terisolasi versus waktu sebelum (----) dan sesudah (-----) perendaman verapamil $\mathrm{HCl}$ 
Secara umum perendaman otot polos trakea marmut terisolasi dengan rebusan antiasma tidak mengurangi kontraksi otot polos yang dipicu pemberian $\mathrm{CaCl}_{2}$. Rebusan antiasma 3 tampak menghambat kontraksi otot polos trakea pada menit ke 14 hingga 26, ditunjukkan dengan adanya perbedaan persen kontraksi tanpa dan dengan perendaman rebusan antiasma. Hasil yang berbeda ditunjukkan oleh verapamil $\mathrm{HCl}$ dalam menghambat kontraksi otot polos yang disebabkan pemberian $\mathrm{CaCl}_{2}$. Verapamil mampu menghambat kontraksi otot polos pada menit ke 12 hingga 38, ditunjukkan dengan persen kontraksi dengan perendaman verapamil $\mathrm{HCl}$ yang lebih kecil secara bermakna dibandingkan persen kontraksi tanpa perendaman verapamil $\mathrm{HCl}$. Berdasarkan data tersebut dapat dinyatakan bahwa rebusan antiasma 1 dan 2 tidak mempunyai aktivitas penghambat kontraksi akibat peningkatan kadar ion kalsium intraseluler, sedangkan rebusan antiasma 3 hanya mempunyai aktivitas sebagian.

Penggunaan obat tradisional selama ini sering ditujukan sebagai terapi komplementer. Usaha pencegahan timbulnya penyakit tertentu dan penunjang terapi utama suatu penyakit dapat menjadi tujuan penggunaan obat tradisional. Usaha pencegahan kekambuhan asma dari beberapa guideline dilakukan dengan penggunaan kortikosteroid inhalasi yang dikombinasikan dengan LABA. Pembuktian kemampuan rebusan antiasma dalam pencegahan kekambuhan asma dilakukan melalui uji aktivitas penghambatan kontraksi akibat peningkatan kadar ion kalsium intraseluler. Hasil penelitian menunjukkan bahwa rebusan antiasma 3 berpotensi untuk digunakan sebagai terapi pemeliharaan asma.

\section{Hasil Uji Aktivitas Penghambat Infiltrasi Eosinofil dan Penghambat Udem}

Kejadian asma berhubungan dengan infiltrasi eosinofil pada saluran pernafasan. Penelitian ini mengungkap kemampuan rebusan antiasma dalam menghambat infiltrasi eosinofil di otot polos trakea marmut. Semakin besar kemampuan rebusan antiasma dalam menghambat infiltrasi eosinofil ditunjukkan dengan semakin sedikitnya eosinofil yang ditemukan di otot polos trakea. Rangkuman hasil uji aktivitas rebusan antiasma sebagai penghambat infiltrasi eosiofil dapat dilihat pada gambar 3.

Jumlah eosinofil pada otot polos trakea marmut yang diberi rebusan antiasma 1 dan 3 lebih kecil dibandingkan kelompok kontrol negatif, namun tidak ada perbedaan yang bermakna. Kelompok yang diberi rebusan antiasma 2 jumlah eosinofilnya lebih banyak dibandingkan dengan kelompok kontrol negatif dan secara statistik berbeda bermakna. Berdasarkan hasil ini, dapat dinyatakan bahwa rebusan antiasma 1, 2, dan 3 tidak mempunyai aktivitas sebagai penghambat infiltrasi eosinofil pada otot polos trakea.

Keadaan asma ditandai dengan ditemuinya udem pada otot polos saluran pernafasan. Udem akan mempersempit diameter trakea, sehingga secara klinis menimbulkan sesak nafas. 


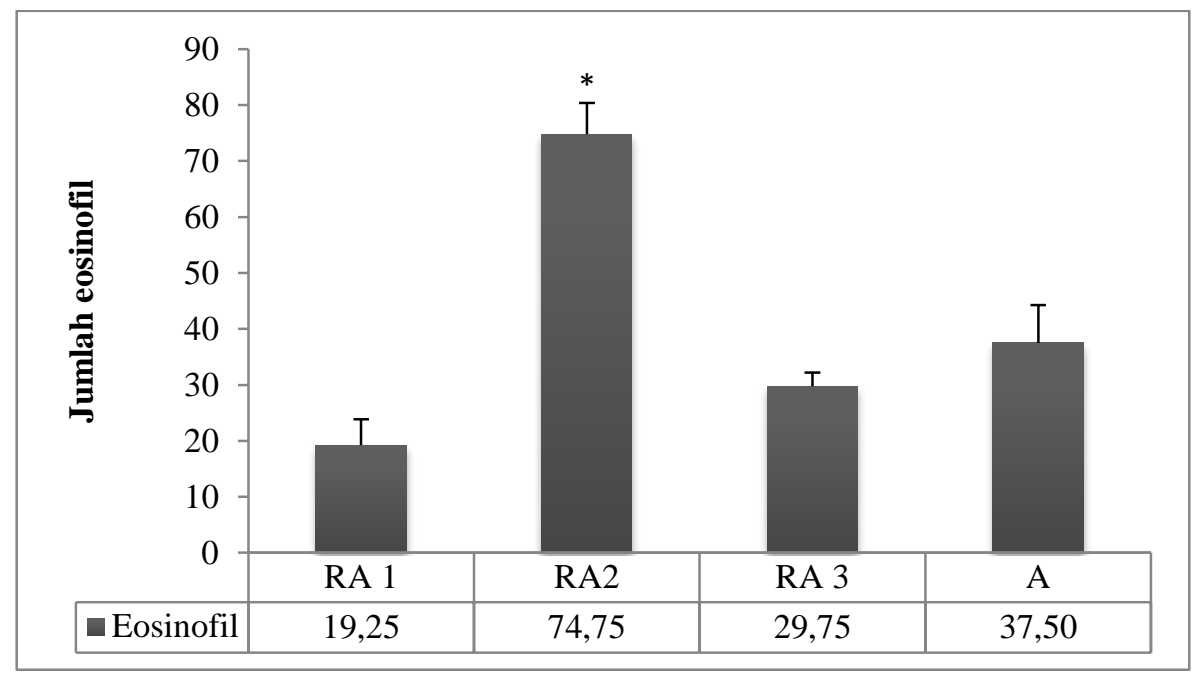

$\begin{array}{lllll}\text { Keterangan: } & \text { RA } 1 \text { : rebusan antiasma } 1 & \text { RA } 2 & \text { : rebusan antiasma } 2 \\ & \text { RA } 3 \text { : rebusan antiasma 3 } & \text { A } & \text { : aqua destillata } \\ & * \text { ada perbedaan bermakna }(p<0,05) \text { dengan aqua destillata }\end{array}$

Gambar 3. Rata-rata jumlah eosinofil pada otot polos trakea marmut akibat perlakuan rebusan antiasma dan aqua destillata

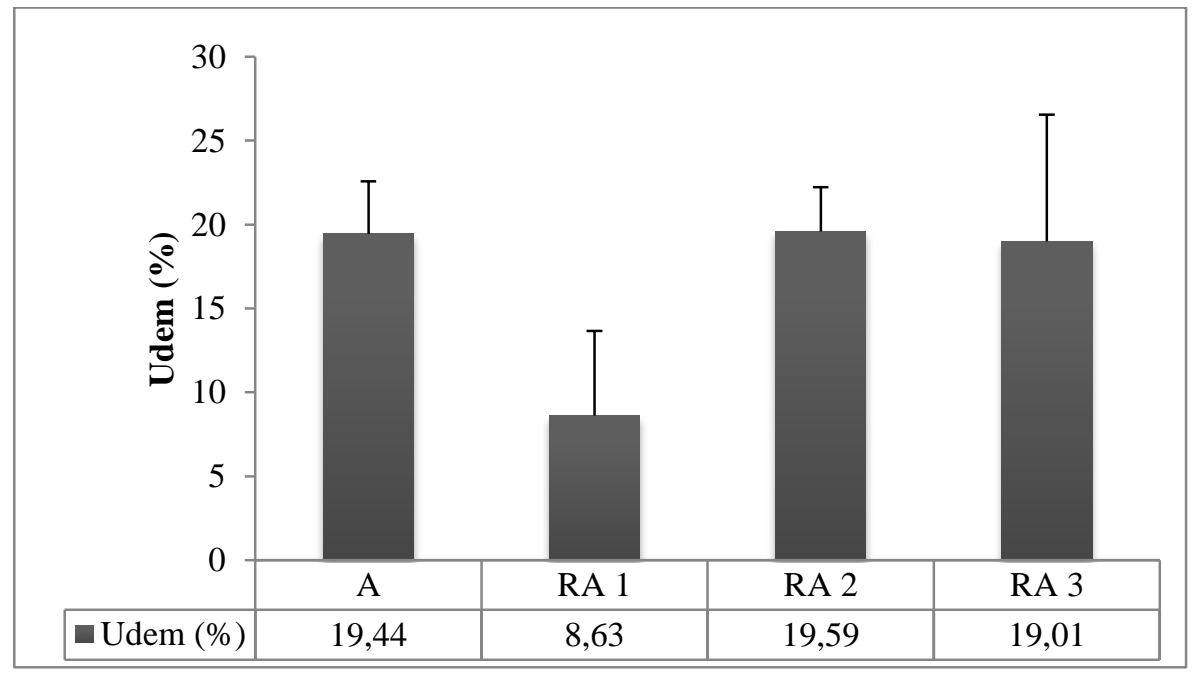

$\begin{array}{lllll}\text { Keterangan: } & \text { RA } 1 & \text { : rebusan antiasma } 1 & \text { RA } 2 & \text { : rebusan antiasma } 2 \\ & \text { RA } 3 & \text { : rebusan antiasma 3 } & \text { A } & \text { : aqua destillata } \\ & * \text { ada perbedaan bermakna }(p<0,05) & \text { dengan aqua destillata }\end{array}$

Gambar 3. Rata-rata persen udem pada otot polos trakea marmut akibat perlakuan rebusan antiasma dan aqua destillata

Besarnya persen udem yang terjadi pada otot polos trakea marmut berbagai kelompok perlakuan terdapat pada gambar 4. Persen udem otot polos trakea marmut akibat rebusan antiasma
1 dan 3 lebih kecil dibandingkan \% udem kelompok kontrol negatif, namun secara statistik tidak ada perbedaan yang bermakna diantara ketiga kelompok tersebut. Berbeda dengan 
rebusan antiasma 1 dan 3 , persen udem pada otot polos trakea marmut yang diberi rebusan antiasma 2 lebih besar daripada kelompok kontrol negatif, namun perbedaan tersebut tidak bermakna. Berdasarkan analisa statistika dapat dikatakan bahwa rebusan antiasma 1, 2, dan 3 tidak mempunyai efek menghambat udem otot polos trakea marmut.

Uji aktivitas rebusan antiasma secara in vivo dilakukan menggunakan marmut yang dibuat asma dengan pemberian ovalbumin. Secara in vivo semua rebusan antiasma tidak mempunyai aktivitas sebagai penghambat infiltrasi eosinofil maupun penghambat udem. Berdasarkan literatur, empat macam tanaman dalam rebusan antiasma berpotensi untuk digunakan sebagai antiasma (Prasaja et al., 2005; Youssouf et al., 2007; Chen dan Er, 2010; Wahyono et al., 2005), namun hasil penelitian tidak menunjukkan hasil yang selaras dengan penelitian sebelumnya. Penggunaan marmut yang dipapari ovalbumin sebagai model hewan uji asma mempunyai keterbatasan dalam hal variasi respon biologis. Prosedur sensitisasi dan pemaparan ovalbumin pada marmut telah dibuat seragam, namun respon marmut kemungkinan beragam, sehingga menjadi keterbatasan dalam pengujian aktivitas secara in vivo. Dugaan ini diperkuat dengan matinya beberapa marmut selama dilakukan penelitian. Pemaparan ovalbumin secara nebulasi dilakukan beberapa kali setelah fase sensitisasi dengan tujuan mempertahankan keadaan asma pada marmut. Kematian marmut kemungkinan disebabkan respon marmut terhadap nebulasi ovalbumin menyebabkan keadaan asma berat. Kematian marmut selama penelitian juga mempengaruhi jumlah replikasi penelitian. Idealnya replikasi penelitian dibuat sebanyak mungkin, sehingga kecenderungan respon hewan uji terhadap perlakuan dapat teramati. Jumlah replikasi yang rendah dalam penelitian ini disertai dengan hasil yang bervariasi antar replikasi yang ditunjukkan dengan besarnya nilai SEM menjadikan hasil penelitian menjadi bias. Perlu dilakukan pengulangan penelitian dengan modifikasi pembuatan marmut sebagai model hewan uji asma. Modifikasi dapat dilakukan dengan menentukan derajat keparahan asma dalam pembuatan model hewan uji asma. Parameter yang dapat digunakan untuk menentukan derajat keparahan asma adalah pengukuran kadar IgE dalam darah. Pengulangan penelitian perlu juga dilakukan dengan jumlah hewan uji yang lebih besar.

\section{KESIMPULAN}

Rebusan antiasma 3 mempunyai aktivitas sebagian dalam menghambat kontraksi akibat peningkatan kadar ion kalsium intraseluler. Semua rebusan antiasma tidak mempunyai aktivitas sebagai penghambat infiltrasi eosinofil dan penghambat udem.

\section{DAFTAR PUSTAKA}

Braman SS. 2006. The global burden of asthma. Chest 130:4S - 12S

Chen YS, Er HM. Antioxidant, antiproliferative and bronchodilatory 
activities of Euphorbia hirta extracts. MJS 29:22 - 29

[Depkes RI] Departemen Kesehatan Republik Indonesia. 1979. Farmakope Indonesia. Ed III. Jakarta: Depkes RI

[Kemenkes RI] Kementerian Kesehatan Republik Indonesia. 2013. Riset kesehatan dasar Riskesdas 2013. Jakarta. Badan Penelitian dan Pengembangan Kesehatan Kementerian Kesehatan Republik Indonesia

Krishna S, Renu S. 2013. Isolation and identification of flavonoids from Cyperus rotundus Linn. in vivo and in vitro. JDDT 3:109 - 113

Kumar S, Malhotra R, Kumar D. 2010. Euphorbia hirta: it's chemistry, traditional and medicinal uses, and pharmacological activities. Pharmacogn Rev 4:58 - 61

Lee TL, Adaikan PG, Lau LC, Ratnam SS, Dambisya YM. 1997. Effects of bupivacain and its isomers on guinea pig tracheal smooth muscle. Methods Find Exp Clin Pharmacol 19:27 - 33

Mahajan SG, Mehta AA. 2011. Suppression of ovalbumininduced Th2-driven airway inflammation by $\beta$-Sitosterol in a guinea pig model of asthma. Eur J Phar 650:458 - 464

Nahak G, Sahu RK. 2011. Phytochemical evaluation and antioxidant activity of Piper cubeba and Piper nigrum. JAPS $01: 153-157$
Nessa F, Ismail Z, Karupiah S, Mohamed N. 2005. RP-HPLC method for the quantitative analysis of naturally occuring flavonoids in leaves of Blumea balsamifera DC. Journal Chromatogr Sci 43:416 - 420

Pang JJ, Xu BB, Li HF, Zhang XY, Zheng TZ. 2002. Inhibition of $\beta$ estradiol on tracheal smooth muscle contraction in vitro and in vivo. Acta Pharmacol Sin 23:273 $-277$

Prasaja Y, Adreanus AS, Sigit JI. 2005. Uji aktivitas antiasma ekstrak etanol daun sembung (Blumea

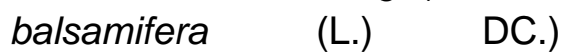
berdasarkan pola pernafasan marmut jantan. [Skripsi]. Bandung: Sekolah Farmasi, Institut Teknologi Bandung

Sulandjari, 2009, Pendekatan Bioregion dalam Pengembangan Budidaya Tanaman Biofarmaka. disampaikan dalam acara Sidang Senat Terbuka Universitas Sebelas Maret Surakarta

Tanaka T, Takahashi R. 2013. Flavonoids and Asthma. Nutrients 5:2128 - 2145

[USDHHS] US Departement of Health and Human Services. 2007. Expert Panel Report 3: Guidelines for the Diagnosis and Management of Asthma. National Heart, Lung and Blood Institute, National Asthma Education and Prevention Program 